\title{
Evaluation of the Clinical Findings and Glycemic Parameters in Patients Newly Diagnosed with Diabetes Mellitus after Being Infected with Coronavirus Disease-2019
}

\section{Koronavirüs Hastalığı-2019 ile Enfekte Olduktan Sonra Yeni Tanı Diabetes Mellitus Saptanan Hastalarda Klinik Bulgular ve Glisemik Parametrelerin Değerlendirilmesi}

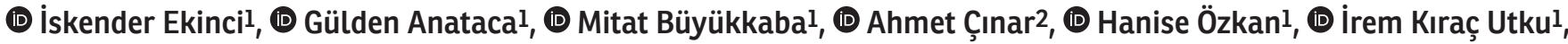 \\ (D) Murat Akarsul, (D) Abdulbaki Kumbasar3, (D) Ömür Tabak1 \\ IUniversity of Health Sciences Turkey, Kanuni Sultan Süleyman Training and Research Hospital, Clinic of Internal Medicine, İstanbul, Turkey \\ ${ }^{2}$ Arnavutköy State Hospital, Clinic of Internal Medicine, İstanbul Turkey \\ 3University of Health Sciences Turkey, Bakırköy Dr. Sadi Konuk Training and Research Hospital, Clinic of Internal Medicine, İstanbul, Turkey
}

\begin{abstract}
Objective: The aim of this study was to analyze patients newly diagnosed with diabetes mellitus (DM) after coronavirus disease-2019 (COVID-19) infection and compare them with type $2 \mathrm{DM}$ patients in terms of clinical findings and glycemic parameters.

Method: This retrospective case-control study was conducted with patients with post-covid DM (PCDM) and newly diagnosed type 2 DM.

Results: Fifty eight patients with PCDM and 57 patients with type 2 DM were included in the study. While 73 of the subjects were male, the mean age of the all subjects was $49.1 \pm 12$ years. The two groups were similar in terms of age, gender distribution, frequency of smoking and family history of DM, and mean body mass index ( $p>0.05$ ). Dry mouth, polyuria, polydipsia, and weight loss were more common in patients with type 2 DM, whereas fatigue was more common in patients with PCDM $(p<0.05)$. Serum creatinine levels were higher in patients with PCDM than in those with type 2 DM ( $p<0.05)$, whereas glycosylated hemoglobin Alc, C-peptide, alanine transaminase, aspartate transaminase, lipid levels and microalbumin/creatinine ratio in spot urine were not different between the two groups ( $p>0.05$ ). One of the microvascular complications, neuropathy, was more common in patients with type $2 \mathrm{DM}$ ( $p<0.05$ ). The frequency occurrence of diabetic ketoacidosis at the time of diagnosis of DM was similar in the groups ( $p>0.05)$.

Conclusion: In this study, PCDM patients were found to be different from type 2 DM in terms of symptoms and signs, but very similar to type 2 DM patients in terms of metabolic parameters.

Keywords: Diabetes mellitus, COVID-19, post COVID diabetes mellitus, neuropathy, diabetic ketoacidosis
\end{abstract}

Cite as: Ekinci I, Anataca G, Büyükbaba M, Çınar A, Özkan H, Utku IK, Akarsu M, Kumbasar A, Tabak Ö. Evaluation of the Clinical Findings and Glycemic Parameters in Patients Newly Diagnosed with Diabetes Mellitus after Being Infected with Coronavirus Disease-2019. IKSSTD 2021;13(3):227-35

๑Copyright 2021 by the Istanbul Kanuni Sultan Süleyman Training and Research Hospital / Medical Journal of Istanbul Kanuni Sultan Suleyman published by Galenos Publishing House.

๑Telif Hakkı 2021 Istanbul Kanuni Sultan Süleyman Eğitim ve Araștırma Hastanesi / İstanbul Kanuni Sultan Süleyman Tıp Dergisi, Galenos Yayınevi tarafindan basılmıștır. 
ÖZ

Amaç: Bu çalışmanın amacı koronavirüs hastalı̆ı-2019 (COVID-19) enfeksiyonunu geçirdikten sonra yeni diabetes mellitus (DM) tanısı konulan hastaların klinik bulgular ve glisemik parametreler açııından analiz edilmesi ve tip 2 DM hastaları ile kıyaslanmasııır.

Yöntem: Bu retrospektif olgu-kontrol çalıșmasına post covid DM hastaları (PCDM) ile COVID-19 geçirmemiş olup yeni tip 2 DM tanısı konulan hastalar dahil edilmiștir.

Bulgular: Çalıșmaya PCDM tanısı konulan 58 ve tip 2 DM tanısı konulan 57 hasta dahil edildi. Katılımcıların 73'ü erkek olup yaș ortalaması 49,1 \pm 12 yıl idi. İki grup yaș, cinsiyet dağılımı, sigara içiciliği, ailede DM öyküsü sıklığı ve beden kitle indeksi ortalaması açısından benzerdi (p > 0,05). Tip 2 DM hastalarında ağız kuruluğu, poliüri, polidipsi ve kilo kaybı daha sık iken; PCDM hastalarında halsizlik daha sıktı ( $<<0,05)$. PCDM hasta grubunda serum kreatinin düzeyi tip 2 DM hasta grubundan daha yüksek olup ( $<<0,05)$; glikozile hemoglobin Alc, c-peptit, alanin transaminaz, aspartat transaminaz, lipid düzeyleri ve spot idrarda mikroalbumin/kreatinin oranı iki grup arasında benzerdi ( $p>0,05)$. Mikrovasküler komplikasyonlardan biri olan nöropati tip 2 DM hasta grubunda daha sık idi $(p<0,05)$. Tanı anında diyabetik ketoasidoz bulunma sıklığı iki grup arasında benzerdi $(p>0,05)$.

Sonuç: Bu çalıșmada PCDM hastalarının tip 2 DM hastalarından farklı semptom ve bulgularla prezente olduğu ama metabolik parametreler açısından tip 2 DM hastaları ile çok benzer olduğu görülmüştür.

Anahtar kelimeler: Diabetes mellitus, COVID-19, COVID-19 sonrası diabetes mellitus, nöropati, diyabetik ketoasidozis

\section{INTRODUCTION}

Coronavirus disease-2019 (COVID-19) is a systemic disease that can affect multiple organs and systems, especially the lungs and vascular endothelium. The pathological processes caused by the disease are not only limited to the active infection period, but also continue after the acute infection has resolved. The pancreas, one of the endocrine organs, is also one of the target organs, and the damage in this organ may be directly related to the organ involvement of the virus, or it may be a reflection of the systemic inflammatory response.

COVID-19 is associated with acute complications, such as diabetic ketoacidosis (DKA)and deterioration of glycemic regulation, in patients with diabetes mellitus (DM) and may cause hyperglycemia and even DM in non-diabetic individuals ${ }^{(1,2)}$. One of the possible reasons for this is the presence of angiotensin converting enzyme-2 (ACE-2) receptors, which act as receptors for viruses, in pancreatic $\beta$ cells, and viruses damage pancreatic $\beta$ cells with a direct cytotoxic effect. After the virus enters the $\beta$ cells of the pancreas, it causes down-regulation of ACE-2 synthesis and increases the secretion of angiotensin, which in turn impairs insulin secretion ${ }^{3}$. Another possible reason for the deterioration of glycemic regulation is inflammation and an extreme systemic immune response observed in COVID-19 infection. It is believed that some drugs, especially steroids, used in the treatment of COVID-19 may be responsible for the development of these conditions ${ }^{(3)}$.

Post-COVID syndrome is defined as a condition in which COVID-19-related symptoms and signs that occur during or after the illness last longer than 12 weeks and cannot be associated with an alternative diagnosis. These symptoms can last up to 6 months and include weakness, fatigue, shortness of breath, joint pain, and cough ${ }^{(4,5)}$. Whether post-COVID DM (PCDM) is associated with $\beta$-cell damage or excessive systemic inflammation response, whether the damage caused by COVID-19 infection on pancreatic $\beta$ cells is permanent or temporary, and the duration of the recovery period in case of temporary $\beta$-cell damage has not yet been elucidated ${ }^{(5)}$.

How the presence of DM affects the course of COVID-19 and its relationship with mortality are examined in detail in literature, but the PCDM that occurs during or after the course of COVID-19 has not been adequately examined, especially in terms of its clinical features. This study aimed to analyze the patients diagnosed with PCDM and to compare clinical features and laboratory parameters of these patients with those of patients newly diagnosed with type-2 DM who were not infected with COVID-19.

\section{METHOD}

This study was conducted at the Department of Internal Medicine, Health Sciences University, Kanuni Sultan Süleyman Training and Research Hospital. The protocol for study was approved by the University of Health Sciences Turkey Kanuni Sultan Süleyman Research and Training Hospital's Ethical Committee (number: KAEK/2021.03.95), and the study was performed in accordance with the Helsinki Declaration.

\section{Study Sample}

This single-center retrospective case-control study included patients older than 18 years of age who applied 
to the outpatient clinic between December 1, 2020 and March 1, 2021 and were diagnosed with DM according to the American Diabetes Association criteria. Patients with PCDM included in the study were those who were diagnosed with DM within 90 days of being infected with COVID-19. As the symptoms and signs detected within 90 days after being infected with COVID-19 in the literature are evaluated within the scope of post-COVID syndrome, we also considered this period as 90 days in our study. Patients who were not infected with COVID-19 and were diagnosed with new type-2 DM were also included in the study for comparison of their findings with those of patients with PCDM.

\section{Exclusion Criteria}

Pregnant women and those who breastfeed; patients with type-1 DM having autoantibody positivity; and patients with impaired fasting glucose, impaired glucose tolerance, or a DM diagnosis in the pre-diagnosis period according to the hospital records were excluded from the study.

\section{Patient Assessment}

Age, sex, smoking habits of all patients, and the presence or absence of a history of DM in the family were recorded. Data regarding height and weight were obtained from the system, and body mass index (BMI) was calculated by dividing the weight by the square of the height $(\mathrm{kg} /$ $\mathrm{m}^{2}$ ). The complaints of the patients at the time of visit to the hospital when they were diagnosed with DM and whether any of the acute complications of diabetes, such as diabetic ketoacidosis, hyperosmolar non-ketotic coma, and hypoglycemia, were present during the same visit were recorded. The presence of microvascular complications of DM (nephropathy, retinopathy, and neuropathy) and comorbidities were recorded. Whether or not the patients had COVID-19 was scanned through the hospital system. Data on the time of diagnosis of COVID-19, whether patients with the disease contracted it at home or in the hospital, and whether these patients who were admitted to the hospital received steroid treatment, were obtained from the hospital information system. The number of days for the diagnosis of DM after the diagnosis of COVID-19 in patients with PCDM was noted. Patients diagnosed with PCDM within 30 days of being infected with COVID-19 were defined as "patients with PCDM diagnosed in the early period"; patients diagnosed with PCDM within 31-90 days of being infected with COVID-19 were defined as "patients with PCDM diagnosed in the late period."

\section{Laboratory Measurements}

Within the scope of the study, fasting blood glucose, glycosylated hemoglobin Alc (HbAlc), C-peptide, creatinine, alanine transaminase (ALT), aspartate transaminase (AST), and lipid panel [low-density lipoprotein (LDL) cholesterol, high-density lipoprotein (HDL) cholesterol, triglyceride, and total cholesterol] values as well as the microalbumin/ creatinine ratio in spot urine measured at the time of the visit when the patients were diagnosed with DM were noted.

\section{Statistical Analysis}

Data were statistically analyzed using SPSS for Windows 26.0 (IBM Corporation, Chicago, IL, USA). The mean, standard deviation, median, lowest, highest, frequency, and ratio values were used as descriptive statistics. Distribution of the variables was measured by the Kolmogorov-Smirnov test. The independent sample t-test and the Mann-Whitney $U$ test were used in the analysis of independent quantitative data. The chi-square test was used in the analysis of independent qualitative data. The Spearman's correlation analysis was used for determining correlation. A $p$ value of $<0.05$ was considered statistically significant.

\section{RESULTS}

A total of 115 patients were included in the study. Of these, 73 were males and the mean age was $49.1 \pm 12$ years. A total of 58 patients had PCDM, and 57 had type-2 DM. Data regarding patient demography (sex distribution, weight, BMI, presence of a history of DM in the family, smoking status, and presence of comorbidities), symptoms and findings detected at the time of admission, presence of the DM-related microvascular complications, and laboratory findings at the time of diagnosis are presented in Table 1.

Patients with PCDM and those with type-2 DM had similar demographic data. Dry mouth, polyuria, polydipsia, and weight loss were more common in patients with type-2 DM, whereas fatigue was more common in patients with PCDM. The frequency of occurrence of diabetic ketoacidosis (DKA) at the time of diagnosis of DM was similar in the PCDM and type-2 DM groups. Neuropathy, one of the microvascular complications, was more common in patients with type-2 DM. Serum creatinine levels were higher in patients with PCDM than in those with type-2 DM, whereas other laboratory parameters were not different between the two groups.

Only about a quarter of the patients who were classified according to the obesity classification based on their BMI level had normal weight; the rest had a mean BMI of $\geq 25 \mathrm{~kg} /$ 
$\mathrm{m}^{2}$. The distribution of the patients in the two groups based on the obesity classification was similar (Table 2).

When the severity of COVID-19 in patients with PCDM was examined, 36 of these patients were found to not require hospitalization for this disease, and 22 of them were found to require hospitalization. The diagnosis of $\mathrm{DM}$ in these patients was made on average of $38 \pm 24$ days (minimum $=6$ days, maximum $=90$ days) after the diagnosis of COVID-19. This period was $41.19 \pm 27.51$ days in those who were not

Table 1. Evaluation of patients in terms of demographic data, admission symptoms and signs, microvascular complications, and laboratory parameters

\begin{tabular}{|c|c|c|c|c|c|}
\hline & & $\begin{array}{l}\text { All patients } \\
\mathrm{n}=115\end{array}$ & $\begin{array}{l}\text { Patients with type-2 } \\
\text { DM } \\
\mathrm{n}=57\end{array}$ & $\begin{array}{l}\text { Patients with PCDM } \\
\mathrm{n}=58\end{array}$ & $\mathbf{p}$ \\
\hline Age, yea & & $49.1 \pm 12$ & $48.6 \pm 10.8$ & $49.6 \pm 13.1$ & 0.644 \\
\hline Gender & Male, $\mathrm{n}$ & 73 & 37 & 36 & 0752 \\
\hline & Female, $\mathrm{n}$ & 42 & 20 & 22 & \\
\hline The pres & $f$ a history of DM in the family, $n$ & 70 & 38 & 32 & 0.250 \\
\hline Smoker, & & 86 & 42 & 44 & 0.788 \\
\hline Presenc & norbid disease, $n$ & 42 & 17 & 25 & 0.139 \\
\hline Hyperte & & 38 & 16 & 22 & 0.261 \\
\hline Weight, & & $78.3 \pm 11.6$ & $79.4 \pm 11.8$ & $77.1 \pm 11.3$ & 0.097 \\
\hline BMI, kg/ & & $27.6 \pm 3.99$ & $28 \pm 4.4$ & $27.1 \pm 3.4$ & 0.265 \\
\hline Presenc & $\mathrm{A}$ at admission, $\mathrm{n}(\%)$ & $9(7.8)$ & $4(7)$ & $5(8.6)$ & 0.749 \\
\hline Admissi & iptoms and signs & & & & \\
\hline Dry mou & & $27(23.5)$ & $24(42.1)$ & $3(5.1)$ & $<0.001$ \\
\hline Polyuria & & $43(37.4)$ & $35(61.4)$ & $8(13.7)$ & $<0.001$ \\
\hline Polydips & & $25(21.7)$ & $22(38.5)$ & $3(5.1)$ & $<0.001$ \\
\hline Fatigue, & & $92(80)$ & $35(61.4)$ & $57(98.2)$ & $<0.001$ \\
\hline Weight L & & $13(11.3)$ & $10(17.5)$ & $3(5.1)$ & 0.036 \\
\hline Microva & complications & & & & \\
\hline Nephrop & $(\%)$ & $30(26.1)$ & $16(28)$ & $14(24.1)$ & 0.675 \\
\hline Retinopa & & $2(1.7)$ & $2(3.5)$ & 0 & - \\
\hline Neuropa & & 65 (56.5) & $41(71.9)$ & $24(41.3)$ & 0.001 \\
\hline Laborat & ameters & & & & \\
\hline Glucose, & & $245.2 \pm 105.86$ & $260.26 \pm 100.79$ & $230.3 \pm 109.4$ & 0.066 \\
\hline Creatinir & & $0.79 \pm 0.22$ & $0.74 \pm 0.19$ & $0.84 \pm 0.23$ & 0.022 \\
\hline $\mathrm{HbAlc}, 9$ & & $10.39 \pm 2.61$ & $10.74 \pm 2.59$ & $10.06 \pm 2.6$ & 0.216 \\
\hline C-peptid & & $969.28 \pm 344.15$ & $1004.21 \pm 366.19$ & $934.96 \pm 320.49$ & 0.457 \\
\hline $\mathrm{ALT}, \mathrm{U} / \mathrm{L}$ & & $32.59 \pm 26.26$ & $29.5 \pm 20.2$ & $35.6 \pm 30.9$ & 0.138 \\
\hline AST, U/L & & $24.78 \pm 15.78$ & $20.8 \pm 10$ & $28.6 \pm 19.1$ & 0.053 \\
\hline LDL cho & $\mathrm{L}, \mathrm{mg} / \mathrm{dL}$ & $119.76 \pm 44.04$ & $121 \pm 45.4$ & $116.4 \pm 45.3$ & 0.332 \\
\hline HDL cho & $\mathrm{L}, \mathrm{mg} / \mathrm{dL}$ & $40.47 \pm 9.69$ & $40.4 \pm 9.8$ & $40.4 \pm 9.6$ & 0.687 \\
\hline Triglycer & $g / d L$ & $272.42 \pm 255.67$ & $312.6 \pm 320.8$ & $233.5 \pm 164.7$ & 0.311 \\
\hline Total ch & $\mathrm{ol}, \mathrm{mg} / \mathrm{dL}$ & $209.3 \pm 64.24$ & $218 \pm 66$ & $200.7 \pm 61.7$ & 0.069 \\
\hline $\begin{array}{l}\text { Microalt } \\
\mathrm{mg} / \mathrm{g}\end{array}$ & creatinine ratio in spot urine, & $42.36 \pm 88.67$ & $44.76 \pm 95.46$ & $40 \pm 82.22$ & 0.368 \\
\hline
\end{tabular}


hospitalized due to COVID-19, whereas it was $33.63 \pm 18.13$ days in those who were hospitalized and followed up; it was not different between the two groups ( $p>0.05$ ). Patients with PCDM who required hospitalization and who were followed up as outpatients were similar in terms of age, sex distribution, history of DM in the family, smoking, anthropometric measurements, complaints at admission, and the presence of microvascular complications of DM, whereas the presence of comorbidities and the incidence of hypertension were higher in patients who were hospitalized (Table 2). Although

Table 2. Evaluation of patients with post covid diabetes mellitus according to the type of recovery from COVID-19 infection in terms of demographic data, admission symptoms and signs, microvascular complications, and laboratory parameters

\begin{tabular}{|c|c|c|c|c|}
\hline & & $\begin{array}{l}\text { Patients with PCDM who did } \\
\text { not require hospitalization for } \\
\text { COVID-19 infection } \\
n=36\end{array}$ & $\begin{array}{l}\text { Patients with PCDM who required } \\
\text { hospitalization for COVID-19 } \\
\text { infection } \\
\mathrm{n}=22\end{array}$ & p \\
\hline \multicolumn{2}{|c|}{ Age, years } & $47.69 \pm 12.28$ & $52.9 \pm 14.16$ & 0.145 \\
\hline \multirow[t]{2}{*}{ Gender } & Male, $n$ & 22 & 14 & \multirow{2}{*}{0.847} \\
\hline & Female, $\mathrm{n}$ & 14 & 8 & \\
\hline \multicolumn{2}{|c|}{ The presence of a history of DM in the family, $n$} & 19 & 13 & 0.639 \\
\hline \multicolumn{2}{|c|}{ Smoker, n } & 29 & 15 & 0.285 \\
\hline \multicolumn{2}{|c|}{ Presence of comorbid disease, $\mathrm{n}$} & 10 & 15 & 0.003 \\
\hline \multicolumn{2}{|c|}{ Hypertension, $\mathrm{n}$} & 10 & 12 & 0.041 \\
\hline \multicolumn{2}{|c|}{ Weight, kg } & $77.5 \pm 9.78$ & $76.68 \pm 13.79$ & 0.793 \\
\hline \multicolumn{2}{|c|}{$\mathrm{BMI}, \mathrm{kg} / \mathrm{m}^{2}$} & $26.86 \pm 2.91$ & $27.64 \pm 4.13$ & 0.444 \\
\hline \multicolumn{5}{|c|}{ Admission symptoms and signs } \\
\hline \multicolumn{2}{|c|}{ Dry mouth, n (\%) } & $2(5.5)$ & $1(4.5)$ & 0.866 \\
\hline \multicolumn{2}{|c|}{ Polyuria, n (\%) } & $7(19.4)$ & $1(4.5)$ & 0.110 \\
\hline \multicolumn{2}{|c|}{ Polydipsia, n (\%) } & $2(5.5)$ & $1(4.5)$ & 0.866 \\
\hline \multicolumn{2}{|c|}{ Fatigue, n (\%) } & $36(100)$ & $21(95.4)$ & 0.197 \\
\hline \multicolumn{2}{|c|}{ Weight loss, n (\%) } & $3(8.3)$ & - & - \\
\hline \multicolumn{5}{|c|}{ Microvascular complications } \\
\hline \multicolumn{2}{|c|}{ Nephropathy, n (\%) } & $7(19.4)$ & $7(31.8)$ & 0.350 \\
\hline \multicolumn{2}{|c|}{ Retinopathy, n (\%) } & - & - & - \\
\hline \multicolumn{2}{|c|}{ Neuropathy, n (\%) } & $16(44.4)$ & $8(36.3)$ & 0.544 \\
\hline \multicolumn{5}{|c|}{ Laboratory parameters } \\
\hline \multicolumn{2}{|c|}{ Glucose, mg/dL } & $223 \pm 93.6$ & $242.5 \pm 133.2$ & 0.736 \\
\hline \multicolumn{2}{|c|}{ Creatinine, mg/dL } & $0.8 \pm 0.21$ & $0.9 \pm 0.26$ & 0.138 \\
\hline \multicolumn{2}{|c|}{$\mathrm{HbAlc}, \%$} & $10.27 \pm 2.65$ & $9.7 \pm 2.55$ & 0.506 \\
\hline \multicolumn{2}{|c|}{ C-peptide, pmol/L } & $985.47 \pm 326.91$ & $852.31 \pm 298.58$ & 0.138 \\
\hline \multicolumn{2}{|c|}{$\mathrm{ALT}, \mathrm{U} / \mathrm{L}$} & $27.69 \pm 16.08$ & $48.59 \pm 43.37$ & 0.016 \\
\hline \multicolumn{2}{|c|}{ AST, U/L } & $22.77 \pm 12.34$ & $38.22 \pm 24.27$ & 0.005 \\
\hline \multicolumn{2}{|c|}{ LDL cholesterol, mg/dL } & $114.52 \pm 31.8$ & $119.59 \pm 62.24$ & 0.726 \\
\hline \multicolumn{2}{|c|}{ HDL cholesterol, mg/dL } & $41 \pm 11.08$ & $39.57 \pm 6.73$ & 0.595 \\
\hline \multicolumn{2}{|c|}{ Triglyceride, mg/dL } & $238.02 \pm 178.49$ & $226.27 \pm 143.23$ & 0.962 \\
\hline \multicolumn{2}{|c|}{ Total cholesterol, mg/dL } & $189.55 \pm 44.7$ & $219.8 \pm 81.09$ & 0.127 \\
\hline \multicolumn{2}{|c|}{ Microalbumin/creatinine ratio in spot urine, $\mathrm{mg} / \mathrm{g}$} & $39.52 \pm 91.42$ & $40.79 \pm 66.49$ & 0.936 \\
\hline
\end{tabular}


ALT and AST values were higher in the patients who were hospitalized, the other laboratory parameters were similar among hospitalized and non-hospitalized patients with COVID-19 (Table 2).

When the time of diagnosis of DM was analyzed in patients with PCDM, 37 of these patients were found to have been diagnosed in the early period, and 21 of them were found to have been diagnosed in the late period. The incidence of clinical symptoms was similar between patients with PCDM who were diagnosed with DM in the early and late periods. The frequency of the findings in patients with PCDM who were diagnosed in the early and late periods were as follows, respectively: dry mouth ( 1 vs 2 subjects; $P=0.547$ ), polyuria ( 4 vs 4 subjects; $P=0.443$ ), polydipsia ( 1 vs 2 subjects; $P=$ 0.547 ), fatigue ( 36 vs 21 subjects; $P=1$ ), and weight loss ( 3 vs 0 subjects; $P=0.547)$. Serum creatinine value was higher in patients diagnosed in the early period $(0.9 \pm 0.26$ vs 0.74 $\pm 0.14 ; P=0.019)$, whereas glucose $(244.3 \pm 118.4$ vs. 205.7 $\pm 88.8) ; \mathrm{P}=0.271), \mathrm{HbAlc}(9.9 \pm 2.5$ vs $10.2 \pm 2.7 ; \mathrm{P}=0.846)$, C-peptide (909 \pm 363.9 vs $980.6 \pm 225.7 ; P=0.222)$, ALT (39.3 \pm 35.7 vs $29 \pm 18.7 ; P=0.145)$, AST (30.2 \pm 22.4 vs $25.7 \pm 11.4$; $P=0.697)$, and the microalbumin/creatinine ratio in spot urine $(55.1 \pm 99.3$ vs $13.2 \pm 18.3 ; P=0.387)$ were not different between PCDM patients diagnosed in the early and late period. A total of 21 of the patients diagnosed with PCDM in the early period were treated for the disease as outpatients, whereas 16 were hospitalized. Further, 15 of the patients diagnosed with PCDM in the late period were treated for the disease as outpatients and 6 required hospitalizations $(P>$ 0.05). Although the incidence rate of nephropathy was higher in the patients diagnosed with PCDM in the early period (35.1\% vs 4.7\%; $P=0.011$ ), the incidence rate of neuropathy was similar between patients diagnosed with PCDM in the early and late periods ( $45.9 \%$ vs. $33.3 \%$; $P=0.413$ ).

The results of the correlation analysis performed in patients with PCDM are presented in Table 3. These analyses showed that each of glucose, HbAlc, and microalbuminuria/ creatinine ratio in spot urine had a positive and significant correlation with the others. In addition, C-peptide level was found to have a negative correlation with glucose, HbAlc, and microalbumin/creatinine ratio in spot urine.

\section{DISCUSSION}

This study found that typical diabetes-related symptoms and signs, such as polyuria, polydipsia, and dry mouth were very rare in patients with PCDM; however, fatigue, which is one of the primary symptoms of COVID-19, was present in almost all patients. These patients, who had different presentations in terms of clinical symptoms, were found to be very similar to patients with type-2 DM in terms of metabolic parameters and microvascular complications. Patients with PCDM who survived COVID-19 as outpatients and the PCDM patients who survived COVID-19 because of hospitalization had similar findings in terms of clinical findings, metabolic parameters, and the incidence of DM-related microvascular complications. Additionally, comorbidities were more common and transaminase levels were higher in the PCDM patient group hospitalized for COVID-19 than those treated as outpatients. Further, patients diagnosed with PCDM in the early period after COVID-19 infection and patients diagnosed with PCDM in the late period had similar characteristics in terms of metabolic parameters.

Few studies in literature analyzed clinical signs and symptoms of PCDM. The primary symptoms detected in 21 PCDM patients diagnosed simultaneously with active COVID-19 infection were fever, cough, widespread body pain, and fatigue, and no acute complications of diabetes were identified in any of them (2). The NOD COVID India study that compared the findings of patients with DM diagnosed during the pandemic (including patients who had and did not have COVID-19) with those of patients with DM diagnosed before the pandemic found that symptoms, such as weakness, polyuria, polyphagia, headache, dizziness, burning during urination, cough, runny nose, sneezing, and shortness of breath, were more common

Table 3. Correlation analysis in patients with post covid diabetes mellitus

\begin{tabular}{|c|c|c|c|c|}
\hline & & Glucose, mg/dL & HbAlc, \% & C-peptide, pmol/L \\
\hline \multirow{2}{*}{ Microalbumin/creatinine ratio in spot urine, $\mathrm{mg} / \mathrm{g}$} & r & 0.487 & 0.375 & -0.344 \\
\hline & $\mathrm{p}$ & $<0.001$ & 0.004 & 0.008 \\
\hline C-peptide, pmol/L & $\mathrm{p}$ & 0.001 & $<0.001$ & \\
\hline $\mathrm{HbAlc}$ \% & r & 0.629 & & \\
\hline
\end{tabular}


in the group of patients diagnosed during the pandemic period; however, patients who did and did not have COVID-19 were not compared in terms of these symptoms ${ }^{(6)}$. In the same study, it was stated that patients who did and did not have COVID-19 were similar in terms of age, sex distribution, rate of smoking and alcohol use, presence of a history of diabetes in the family, and mean BMI. In the CORONADO study, patients diagnosed with DM within one week after the diagnosis of COVID-19 infection during hospitalization were defined as having PCDM. The CORONADO study concluded that patients with PCDM and those with type 2 DM were similar in terms of age, sex distribution, smoking habits, and BMI, but comorbidities, such as hypertension and dyslipidemia, were less common in patients with PCDM ${ }^{(7)}$. A study by Li et al. ${ }^{\left({ }^{8}\right)}$ found that the most common symptoms of patients who were newly diagnosed with DM during active COVID-19 infection were fever and cough and that half of these patients had fatigue, but no data on symptoms, such as polyuria, polydipsia, and dry mouth, have been reported. In addition to these studies, the PCDM case series of three cases by Suwanwongse and Shabarek. ${ }^{(9)}$, reported that the complaints of polyuria, polydipsia, and fatigue were present in all cases, and nausea, vomiting, and weight loss were observed in one patient in addition to these complaints. In another study, the data of three patients who presented with DKA and were diagnosed with PCDM were presented ${ }^{(10)}$. Besides that, the demographic data in our study were similar to the results of the NOD COVID India and CORONADO study; the differences in clinical symptoms between the PCDM and type 2 DM patients were also analyzed in the present study. In our study, almost all patients with PCDM complained of fatigue, followed by polyuria (13.7\%), polydipsia (5.1\%), weight loss (5.1\%), and dry mouth (5.1\%). The frequency of these symptoms did not differ in patients with PCDM in our study both in patients who were treated as outpatients as well as those who were hospitalized due to COVID-19 and in patients who were diagnosed as having PCDM in the early or late period after the COVID-19 infection. In our study, five of the patients with PCDM had DKA, whereas none of the patients had acute complications of diabetes, including hyperosmolar non-ketotic coma and hypoglycemia. In our study, the incidences of comorbidities did not differ between patients with PCDM and those with type 2 DM and was higher in patients with PCDM who were hospitalized because of COVID-19 than in those who were treated for COVID-19 as outpatients.

In the NOD COVID India study, parameters, such as fasting blood glucose, postprandial blood glucose, C-peptide, and
HbAlc, did not differ between patients who were newly diagnosed with DM with and without a history of COVID-19 infection ${ }^{(6)}$. In the CORONADO study, it was reported that fasting blood glucose, HbAlc, ALT, and AST levels were similar between patients with PCDM and those with type $2 \mathrm{DM}$ and that renal functions were better and the mean estimated glomerular filtration rate was higher in patients with PCDM ${ }^{(7)}$. In our study, fasting blood glucose, C-peptide, and $\mathrm{HbAlc}$ values were similar between the patients with PCDM and those with type $2 \mathrm{DM}$. Additionally, contrary to the findings in the CORONADO study, we found that the renal function was worse and the serum creatinine value was higher in patients with PCDM than those in patients with newly diagnosed type-2 DM. Along with these findings, we observed that lipid levels (LDL cholesterol, HDL cholesterol, triglyceride, and total cholesterol) and microalbumin/ creatinine ratio in spot urine were similar in patients with PCDM and newly diagnosed type 2 DM. Further, we found that transaminase levels were higher in patients with PCDM who were hospitalized for COVID-19 infection compared with those who were treated as outpatients for COVID-19 (all other parameters were similar) and that the serum creatinine levels were higher in patients who were diagnosed with PCDM in the early period after COVID-19 infection compared with those who were diagnosed with PCDM in the late period after COVID-19 infection (all other parameters were similar).

Although PCDM may occur simultaneously with active COVID-19 infection, cases have been reported months after recovery from the active phase of the disease. A metaanalysis stated that the mean incidence of PCDM was $14.4 \%$ and that this diagnosis was usually made within 1-3 days during the active COVID-19 infection ${ }^{(11)}$. Studies analyzing patients who simultaneously had DM with active COVID-19 infection and who were diagnosed within the first week after hospitalization for the infection have been reported $(2,8)$. A case series of three patients with PCDM reported that the first case was diagnosed with DM during the active COVID-19 infection period and the second and third cases were diagnosed 8 and 10 weeks after the active infection, respectively ${ }^{(9)}$. Some PCDM cases presenting with DKA or acute pancreatitis during the active COVID-19 infection were also reported $(10,12,13)$. It has been stated that the diagnosis of PCDM was made on different days of the active infection period in patients infected with severe acute respiratory syndrome coronavirus-1 (SARS-CoV-1) (14). In our study, the mean duration from COVID-19 infection to the diagnosis of PCDM in patients with PCDM was $38 \pm 24$ days (minimum 6 days, maximum 90 days). 
A total of $62 \%$ of the patients with PCDM in our study were male, and this male sex predominance was consistent with the data reported in literature. A total of $76.2 \%$ of the patients were male in the study by Sathish et al. ${ }^{(11)}, 64.2 \%$ were male in the CORONADO study, $61.7 \%$ were male in the study by $\mathrm{Li}$ et al. ${ }^{(8)}$, and $52.3 \%$ were male in the NOD COVID India study $(2,6-8)$. In a case series of three cases with PCDM by Kuchay et al. ${ }^{(10)}$, in a case study of three cases presenting with acute pancreatitis, and in a study by Reddy et al. ${ }^{(12)}$ on two cases with DKA, all the patients were reported as being male ${ }^{(13)}$. Additionally, in a case series on three cases by Suwanwongse and Shabarek. ${ }^{(9)}$, two of the patients were male.

In our study, $55.1 \%$ of the patients had a history of DM in the family, which was consistent with reports in literature. This rate was reported as $40.9 \%$ in the NOD COVID India study ${ }^{(6)}$. It was reported that there was a family history of DM in two of the three cases reported by Suwanwongse and Shabarek. ${ }^{(9)}$, and in one of the two cases in the study by Reddy et al. ${ }^{(12)}$.

In our study, the mean BMI in patients with PCDM was calculated as $27.1 \mathrm{~kg} / \mathrm{m}^{2}$, and it was determined that only $27.5 \%$ of these patients had normal weight; all the remaining patients were overweight or obese. The mean BMI in patients with PCDM was reported as $27.7 \mathrm{~kg} / \mathrm{m}^{2}$ in the CONORADO study, $27.8 \mathrm{~kg} / \mathrm{m}^{2}$ in the NOD COVID study, and $24.4 \mathrm{~kg} / \mathrm{m}^{2}$ in the study by Li et al. ${ }^{(6-8)}$. In many case series, all patients were reported to be overweight or obese $(9,10,13)$. This indicates that the patient sample included in our study is comparable with reports in literature in terms of BMI.

In this study, we also analyzed microvascular complications that had not been presented before in patients with PCDM. In our study, the incidence of nephropathy in patients with PCDM was 24.1\%, whereas the incidence of neuropathy was $41.3 \%$. We found that the incidence of nephropathy was similar in patients with type $2 \mathrm{DM}$ and in those with PCDM, whereas neuropathy was more common in patients with type $2 \mathrm{DM}$. The patients were not compared in terms of retinopathy as only a small number of patients had undergone ophthalmologic examination. Both nephropathy and neuropathy did not differ in terms of their incidence in patients with PCDM who had COVID-19 and were treated as outpatients or were hospitalized. The incidence of nephropathy was higher in patients diagnosed with PCDM in the early period than in patients diagnosed with PCDM in the late period, whereas the incidence of neuropathy did not differ between these patients.

It is believed that the development of PCDM may be related to the severity of COVID-19. The level of systemic inflammatory response, the risk of cytokine storm development, and the possibility of developing organ damage may increase with the increase in the disease severity. In a study involving 120 patients, Yang et al. reported that the incidence of PCDM was $53.85 \%$ in the critical patient group and $13.95 \%$ in the moderate + severe patient group ${ }^{(15)}$. Further, the study found that fasting blood sugar tended to decrease in recovering patients but remained high in patients for whom the disease was fatal ${ }^{(15)}$. A study in which 47780 patients who had COVID-19 were followed up for approximately 4.6 months after discharge reported that newly diagnosed DM was detected in $4.9 \%$ of these patients and that this rate was higher both in patients who needed intensive care for COVID-19 and in patients older than 70 years of age ${ }^{(16)}$. In our study, the patients diagnosed with PCDM could not be grouped according to the severity of the disease due to lack of data, but they were grouped as outpatients or those who required hospitalization and analyzed in terms of DM-related parameters. Further, we observed that fasting blood glucose, HbAlc, C-peptide, and lipid levels; microalbumin/creatine ratio in spot urine; and the incidence of microvascular complications were not different between patients with PCDM who were hospitalized and those who were treated as outpatients for COVID-19.

Whether pancreatic $\beta$ cell damage caused by COVID-19 infection is temporary or permanent has still remains to be elucidated. However, in a study in which 39 patients infected with SARS-CoV-1 were followed up, 14 patients were diagnosed with PCDM on the 3rd day of hospitalization and 20 patients were diagnosed with PCDM in the 2nd week of hospitalization ${ }^{(14)}$. It was reported that six patients at the time of discharge and only two patients at the end of three years were still diabetic ${ }^{(14)}$. There is a high possibility that this damage may be temporary and reversible based on the study by Yang et al. ${ }^{(14)}$. In order to elucidate this point, studies with long-term follow-up of patients with PCDM diagnosed after being infected with COVID-19 are warranted.

\section{Study Limitations}

Although we believe that the contribution of our study to the existing literature is significant, there are several limitations of our study. An important limitation of our study is that the sample size was small to make generalizations. Exclusion of patients with pre-diabetes, impaired fasting glucose, and impaired glucose tolerance was another limitation of our study. Although the level of $\mathrm{C}$-peptide was assessed as an indicator of pancreatic $\beta$ cell damage, the fact that the pancreatic enzyme levels were not evaluated as an indicator 
of inflammation in the pancreas in this infection, which is characterized by systemic inflammation, can be considered as a limitation. Another limitation is the incomplete data gathered on the severity of the course of COVID-19 infection and the inability to group patients as having mild, moderate, and severe disease. We tried to overcome this limitation by grouping patients as outpatients with COVID-19 and as those who required hospitalization for COVID-19.

\section{CONCLUSION}

Thus, it can be concluded that the clinical findings in patients with PCDM are very different from those in patients with type-2 DM, but their laboratory parameters are similar to those in patients with type-2 DM. In addition, when patients with PCDM were grouped according to the severity of COVID-19 infection and the time from COVID-19 infection to the diagnosis of PCDM, there were no obvious differences found in either clinical findings or laboratory parameters. In order to identify whether this clinical picture is a new type of DM or a typical type-2 DM triggered by COVID-19 infection and whether the pathological changes observed in PCDM is temporary or permanent, studies with larger samples with long-term follow-up of these patients are warranted.

\section{Ethics}

Ethics Committee Approval: The protocol for study was approved by the University of Health Sciences Turkey Kanuni Sultan Suleyman Research and Training Hospital's Ethical Committee (number: KAEK/2021.03.95), and the study was performed in accordance with the Helsinki Declaration.

Informed Consent: Obtained.

Peer-review: Externally peer reviewed.

\section{Authorship Contributions}

Concept: I.E., G.A., M.B., A.Ç., H.Ö., İ.K.U., M.A., A.K., Ö.T., Design: I.E., G.A., M.B., A.Ç., H.Ö., I.K.U., M.A., A.K., Ö.T., Data Collection or Processing: İ.E., G.A., M.B., A.Ç., H.Ö., İ.K.U., M.A., A.K., Ö.T., Analysis or Interpretation: I.E., G.A., M.B., A.Ç., H.Ö., I.K.U., M.A., A.K., Ö.T., Literature Search: I.E., G.A., M.B., A.Ç., H.Ö., I.K.U., M.A., A.K., Ö.T., Writing: I.E., G.A., M.B., A.Ç., H.Ö., I.K.U., M.A., A.K., Ö.T.

Conflict of Interest: No conflict of interest was declared by the authors.

Financial Disclosure: The authors declared that this study received no financial support.

\section{REFERENCES}

1. Alsadhan I, Alruwashid S, Alhamad M, et al. Diabetic ketoacidosis precipitated by Coronavirus disease 2019 infection: case series. Curr Ther Res Clin Exp. 2020;93:100609. doi: 10.1016/j.curtheres.2020.100609.

2. Sathish T, Chandrika Anton M. Newly diagnosed diabetes in patients with mild to moderate COVID-19. Diabetes Metab Syndr. 2021;15:569-71. doi: 10.1016/j.dsx.2021.02.034.

3. Ugwueze CV, Ezeokpo BC, Nnolim BI, Agim EA, Anikpo NC, Onyekachi KE. COVID-19 and diabetes mellitus: the link and clinical implications. Dubai Diabetes Endocrinol J. 2020;26:69-77. doi: 10.1159/000511354

4. National Institute for Health and Care Excellence. COVID-19 rapid guideline: managing the long-term effects of COVID-19. 2020. Erişim tarihi. Available from: https://www.nice.org.uk/guidance/ngl88.

5. Nalbandian A, Sehgal K, Gupta A, et al. Post-acute COVID-19 syndrome. Nat Med. 2021;27:601-15. doi: 10.1038/s41591-021-01283-z

6. Ghosh A, Anjana RM, Shanthi Rani CS, et al. Glycemic parameters in patients with new-onset diabetes during COVID-19 pandemic are more severe than in patients with new-onset diabetes before the pandemic: NOD COVID India Study. Diabetes Metab Syndr. 2021;15:215-20. doi: 10.1016/j.dsx.2020.12.033.

7. Cariou B, Pichelin M, Goronflot $\mathrm{T}$, et al. Phenotypic characteristics and prognosis of newly diagnosed diabetes in hospitalized patients with COVID-19: results from the CORONADO study. Diabetes Res Clin Pract. 2021 Feb 9:108695. doi: 10.1016/j.diabres.2021.108695.

8. Li H, Tian S, Chen T, et al. Newly diagnosed diabetes is associated with a higher risk of mortality than known diabetes in hospitalized patients with COVID-19. Diabetes Obes Metab. 2020;22:1897-906. doi: 10.1111/ dom.14099.

9. Suwanwongse K, Shabarek N. Newly diagnosed diabetes mellitus, DKA and COVID-19: Causality or coincidence? A report of three cases. J Med Virol. 2021;93:1150-3. doi: 10.1002/jmv.26339.

10. Kuchay MS, Reddy PK, Gagneja S, Mathew A, Mishra SK. Short term follow-up of patients presenting with acute onset diabetes and diabetic ketoacidosis during an episode of COVID-19. Diabetes Metab Syndr. 2020;14:2039-41. doi: 10.1016/j.dsx.2020.10.015.

11. Sathish T, Kapoor N, Cao Y, Tapp RJ, Zimmet P. Proportion of newly diagnosed diabetes in COVID-19 patients: A systematic review and metaanalysis. Diabetes Obes Metab. 2021;23:870-4. doi: 10.1111/dom.14269.

12. Reddy PK, Kuchay MS, Mehta Y, Mishra SK. Diabetic ketoacidosis precipitated by COVID-19: A report of two cases and review of literature. Diabetes Metab Syndr. 2020;14:1459-62. doi: 10.1016/j.dsx.2020.07.050

13. Szatmary P, Arora A, Thomas Raraty MG, et al. Emerging phenotype of severe acute respiratory syndrome-coronavirus 2-associated pancreatitis. Gastroenterology. 2020;159:1551-4. doi: 10.1053/j. gastro.2020.05.069.

14. Yang JK, Lin SS, Ji XJ, Guo LM. Binding of SARS coronavirus to its receptor damages islets and causes acute diabetes. Acta Diabetol. 2010;47:193-9. doi: 10.1007/s00592-009-0109-4.

15. Yang JK, Jin JM, Liu S, et al. New onset COVID-19-related diabetes: an indicator of mortality. medRxiv. 2020. Preprint doi: https://doi. org/10.1101/2020.04.08.20058040.

16. Ayoubkhani D, Khunti K, Nafilyan V, et al. Post-covid syndrome in individuals admitted to hospital with covid-19: retrospective cohort study. BMJ. 2021;372:n693. doi: 10.1136/bmj.n693. 